\title{
URGENSI SEMIOTIKA \\ DALAM MEMAHAMI BAHASA AGAMA
}

\author{
Akhmad Muzakki
}

Ketua Pusat Kajian Bahasa dan Budaya Fak. Humaniora dan Budaya UIN Malang. Jalan Gajayana No. 50 Telepon (0341) 570872, Faksimile (0341) 570872 Malang 65144

\begin{abstract}
In semiotics, language is a sign having two components such as 'significant' and 'signifie' in which the relation of both is arbitrary. For philosophers interested in language, 'signifie' is not meaningless as language is metaphor. Meaning will always change. Meaning is also metaphorical and also depends on the difference of the readers' background. This concept also works for religious texts that do not use the the last 'signifie' because omitting the meaning of the text will stop the development of Islam for man's goodness. In fact, Islam is a religion that as always relevant with the time.
\end{abstract}

\section{Key words}

Semiotics, Religion, Metaphor, Meaning

\section{Pendahuluan}

Allah SWT memberikan satu kelebihan kepada manusia berupa akal pikiran agar ia mampu menjalankan tugas dan misinya sebagai khalifatullah fi al-ardl. Dan juga karena kasih sayang-Nya, kemudian Allah menurunkan wahyu berupa al-Qur'an melalui Jibril kepada Nabi Muhammad SAW untuk dijadikan rujukan dan referensi dalam kehidupan (way of life). Tercatat dalam sejarah, bahwa al-Qur'an diturunkan secara evolusi dan berkesinambungan (tadrij) selama lebih kurang 23 tahun. Hal ini memberikan kesan bahwa al-Qur'an benar- 
benar berdialog, sekaligus mengoreksi kehidupan umat manusia pada saat itu. (Al-Nabhan, 1981:83).

Pemahaman terhadap al-Qur'an yang diyakini sebagai kitab shalihun li kulli zamanin wa makanin selalu bersifat terbuka dan tidak pernah selesai. Pemahaman selalu berkembang seiring dengan umat Islam yang selalu terlibat dalam penafsiran ulang dari zaman ke zaman. Dengan begitu, tidak semua doktrin dan pemahaman agama berlaku sepanjang waktu dan tempat mengingat gagasan universal Islam tidak semuanya tertampung dalam bahasa yang bersifat lokal-kultural dan terungkap melalui tradisi kenabian. Itulah sebabnya dari zaman ke zaman selalu muncul ulama-ulama tafsir yang berusaha mengaktualkan pesan-pesan al-Qur'an yang tidak mengenal batas akhir. (Hidayat, 1996:23)

Dalam proses pemahaman terdapat tiga faktor yang tidak bisa dipisahkan, yaitu dunia pengarang, dunia teks, dan dunia pembaca. Selain ketiga faktor ini keberadaan konteks juga sangat berperan dalam memahami peristiwa pewahyuan, sebab ayat-ayat al-Qur'an tidak akan dapat dimengerti dengan sempurna kecuali dengan memperhatikan realitas yang melatarbelakanginya. Indikasi ini dapat dilihat dengan munculnya konsep asbab al-nuzul dan nasikh mansukh yang menjadi tema tersendiri dalam studi ulumul Qur'an. Oleh sebab itu, memahami historisitas teks al-Qur'an menjadi penting, meskipun jarak antara pengarang teks (Tuhan) dan manusia sebagai pembaca demikian jauh agar makna dan pesan moral tersebut bisa direfleksikan seiring dengan kemaslahatan.

Perbincangan masalah historitas teks sebenarnya merupakan persoalan klasik yang pernah muncul dalam sejarah peradaban Islam, yaitu antara pemikir Asy`ariyah dengan Mu’tazilah. Historitas teks, seperti yang dipahami Nasr Hamid dengan meminjam paradigma Ferdinand de Saussure di mana konsep kalam ia bedakan dengan konsep lughat (Abu Zaid, 1994:87). Lughat yang dimaksud setara dengan apa yang diistilahkan Saussure dengan langue (bukan parole), yaitu bahasa pada wilayah realitas historis yang dalam hal ini merupakan bagian dari 
kebudayaan. Dalam pengertian umum, langue adalah abstraksi dan artikulasi bahasa pada tingkat sosial budaya, sedangkan parole merupakan ekspresi bahasa pada tingkat individu. (Hidayat, 1996:23) Berdasarkan kerangka ini maka dalam kajian teks-teks al-Qur'an terdapat perbedaan yang tegas antara konsep kalam (yang a-historis) dengan lughat (yang historis). Historisitas teks tidak hanya meliputi ruang dan waktu, melainkan sekaligus ia adalah sebuah teks yang berkaitan erat dengan teks lainnya yang akan menentukan makna teks itu sendiri.

Jadi, teks-teks agama (lughat) tidak terpisah dari struktur budaya tempat ia terbentuk. Sumber teks sama sekali tidak mengesampingkan hakikat keberadaannya sebagai teks linguistik dengan segala implikasi kebahasaanya. Teks terkait dengan ruang dan waktu dalam pengertian historis dan sosiologis. Teks tidak berada di luar kategori bahasa sehingga tidak memiliki kaitan apapun dengan manusia. Jika berinteraksi dengan teks agama ini bertolak dari keberadaannya sebagai linguistik, maka ini tidak berarti mengabaikan watak tekstualitasnya yang spesifik. Sebab karakter tekstualitas al-Qur'an didasarkan pada realitas-realitas kemanusiaan yang provan, yang bersifat sosiologis, kultural, dan kebahasaan. Keberadaan firman Tuhan yang kudus baru menjadi perhatian hanya pada momen di mana "kalam tersebut diposisikan secara manusiawi", yaitu ketika Muhammad mengujarakannya dalam bahasa Arab. (Abu Zaid, 1994: 118)

Dengan mengikuti kerangka berpikir Saussure di mana bahasa dianggap sebagai proses langue, maka tanda-tanda bahasa merupakan fakta sosial. Karena tanda-tanda bahasa mengacu pada konsep dan gambaran mental yang berdiam dalam masyarakat. Artinya, bahwa bahasa barada dalam inti kebudayaan. Dari pengertian ini para semiot mengatakan, bahwa kebudayaan merupakan ekspresi dari berbagai sistem tanda yang pusatnya adalah tanda bahasa. Sehingga keberadaan bahasa dan lingkungan kulturalnya menjadi rujukan untuk menemukan maknanya. Berangkat dari logika ini, al-Qur'an yang menjadi kitab suci juga dapat dipahami dan dikonstruk melalui perkembangan studi budaya, khususnya bidang kajian semiotika. 
Jika semiotika dirumuskan sebagai ilmu tentang tanda, maka jelas al-Qur'an yang historis (lughat) merupakan bidang subur bagi analisis semiotis. Tanda memiliki hubungan yang erat antara penanda (signifiant) dan petanda (signifie). Penanda adalah bunyi atau coretan yang bermakna, sedangkan petanda adalah aspek mental atau makna dari bunyi itu sendiri. (Bertens, 2001:180) Dalam dunia semiotika, semua jenis teks tidak memberikan petanda terakhir. Di kalangan filsuf, misalnya Jacques Derrida, menolak dan tidak mengakui adanya petanda terakhir. Bahasa menurut Derrida, adalah metafora yang tidak mempunyai rujukan final. Makna muncul karena pertukaran metafora, dan makna akan berubah ketika para pelakunya juga berubah. Dengan kata lain, makna selalu bersifat dinamis dan relasional, karena itu, rujukannya bersifat tak terbatas. (Sunardi, 1996: 76) Bertitik tolak dari fenomena di atas, tulisan ini mengangkat satu tema yang dirasa krusial untuk dikembangkan bagi mahasiswa jurusan Bahasa dan Sastra Fakultas Humaniora dan Budaya UIN Malang, yaitu "Urgensi Semiotika Dalam Memahami Bahasa Agama".

\section{Konsep Dasar Semiotika}

Semiotika merupakan sebuah model ilmu pengetahuan sosial dalam memahami dunia sebagai sistem hubungan yang memiliki unit dasar yang disebut "tanda". Semiotika berasal dari kata Yunani, semeion yang berarti tanda. Tanda itu sendiri didefinisikan sebagai sesuatu yang dapat mewakili sesuatu yang lain atas dasar konvensi sosial. (Eco,1976:16) Mengutip Suwardi, istilah semiotika sering digunakan bersama dengan istilah semiologi. Dalam kedua istilah ini tidak terdapat perbedaan yang substantif, tergantung di mana istilah itu populer. Biasanya semiotika lebih mengarah pada tradisi Piercean, sementara istilah semiologi banyak digunakan oleh Saussure. Keduanya merupakan ilmu yang mempelajari hubungan antara signs (tanda-tanda) berdasarkan kode-kode tertentu. Tanda-tanda tersebut akan tampak pada tindak komunikasi manusia lewat bahasa, baik lisan maupun isyarat. (Endraswara, 2003:64) 
Dalam dunia semiotika, seperti ungkap Ferdinand (Zoest,1996:2), bahasa dianggap sebagai "tanda" (sign) yang memiliki komponen significant/penanda (aspek material, seperti suara, huruf, bentuk, gambar, gerak) dan signifie/petanda (aspek mental atau konseptual yang ditunjuk oleh aspek material). Hubungan antara penanda dengan petanda bersifat arbitrer, atau berdasarkan kesepakatan pengguna bahasa. Melakukan analisis tentang tanda orang harus tahu benar mana aspek material dan mana aspek mental. Ketiga aspek ini merupakan aspek-aspek konstitutif suatu tanda, tanpa salah satu unsur ini tidak akan ada sebuah tanda dan kita tidak bisa membicarakannya. Dengan kata lain, setiap tanda linguistik terdiri dari unsur bunyi dan unsur makna. Kedua unsur ini adalah unsur dalam-bahasa (intralingual) yang biasa merujuk atau mengacu kepada referen yang merupakan unsur luar-bahasa (ekstralingual). Misalnya kata buku, tanda ini terdiri dari unsur makna atau yang diartikan, dan unsur bunyi dalam wujud fonem (b, u, k, u) yang mengartikan. Kemudian tanda "buku" mengacu kepada satu referen yang berada di luar bahasa yang menjadi kesepakatan bersama.

Salah satu area penting yang dirambah Barthes dalam studinya tentang tanda adalah peran pembaca. Konotasi walaupun merupakan sifat asli dari tanda, ia masih membutuhkan keaktifan pembaca agar dapat berfungsi. Barthes menjelaskan apa yang disebut sebagai sistem pemaknaan tataran kedua, yang dibangun di atas sistem lain yang telah ada sebelumnya. Sastra merupakan contoh paling jelas sistem pemaknaan tataran kedua yang dibangun di atas bahasa sebagai sistem yang pertama. Sistem kedua ini oleh Barthes disebut dengan konotatif, yang di dalam mythologies-nya secara tegas ia bedakan dari denotatif atau sistem pemaknaan tataran pertama. Denotasi adalah makna paling nyata dari tanda, sedangkan konotasi adalah istilah yang menunjukkan signifikasi tahap kedua. Konotasi mempunyai makna yang subyektif atau paling tidak intersubyektif. Dengan kata lain, denotasi adalah apa yang digambarkan tanda terhadap obyek, sementara konotasi adalah bagaimana menggambarkan tanda tersebut (Sobur, 2001:128). 
Jadi, dalam konsep Barthes tanda konotatif tidak sekedar memiliki makna tambahan, namun juga mengandung kedua bagian tanda denotatif yang melandasi keberadaannya. Konotasi identik dengan operasi ideologi yang disebutnya sebagai mitos, dan berfungsi untuk mengungkapkan dan memberikan pembenaran bagi nilai-nilai dominan yang berlaku dalam suatu periode tertentu. Dalam mitos terdapat pola tiga dimensi, yaitu: penanda, petanda dan tanda, namun sebagai suatu sistem yang unik mitos dibangun oleh suatu rantai pemaknaan yang telah ada sebelumnya atau, dengan lain kata mitos adalah suatu sistem pemaknaan tataran kedua. Di dalam mitos pula sebuah petanda dapat memiliki beberapa penanda (Budiman, 1995:28).

Masih berkaitan dengan semiotika, Jacques Derrida agak bertentangan dengan semiotika struktural yang dikembangkan Saussure yang mengandalkan pada keabadian, kestabilan, dan kemantapan tanda, kode, dan makna. Sebagai seorang pemikir post-strukturalisme, Derrida lebih mampu mengakomodasi dinamika, ketidakpastian, gejolak dan kegelisahan yang mencirikan budaya sebagai chaos. Bila pada semiotika konvensional yang ditekankan adalah proses signifikasi, yaitu memfungsikan tanda sebagai refleksi dari kode sosial yang telah mapan, maka dalam semiotika post-strukturalisme yang ditekankan adalah proses significance, yaitu sebuah proses penciptaan kreatif tanda dan kode yang tanpa batas dan tak terbatas. Dengan kata lain, ungkap Fiske, hubungan antara keberadaan fisik tanda (penanda) dan konsep mental (petanda) dinamakan signification, yaitu sebuah upaya dalam memberi makna terhadap dunia. (Fiske, 1990:44)

Dalam konsep Saussure, trio langage-langue-parole dipergunakan untuk menegaskan obyek kajian linguistiknya. Fenomena bahasa secara umum disebutnya langage, sedangkan langue dan parole merupakan bagian dari langage. Parole adalah menifestasi individu terhadap bahasa yang dapat memberikan makna, sedangkan langue adalah bahasa dalam proses sosial. Saussure dalam hal ini menitikberatkan studi linguistiknya pada langue, karena ia menaruh perhatian pada tandatanda bahasa atau kode-kode bahasa (Rahardjo, 2004:7) 
Langue adalah bahasa sebagai obyek sosial yang murni, dan dengan demikian keberadaannya terletak di luar individu, yakni sebagai seperangkat konvensi-konvensi sistematik yang berperan penting di dalam komunikasi. Langue juga merupakan institusi sosial yang otonom, tidak tergantung kepada materi tanda-tanda pembentuknya. Sebagai sebuah institusi sosial, langue sama sekali bukan tindakan dan tak bisa pula dirancang, diciptakan, atau diubah secara pribadi karena ia pada hakekatnya merupakan kontrak kolektif yang sungguh-sungguh mesti dipatuhi apabila kita ingin bisa berkomunikasi. (Budiman, 2004: 38) Singkat kata, langue adalah bahasa dalam wujudnya sebagai suatu sistem. Ia merupakan fakta sosial. Jadi, langue adalah suatu sistem kode yang diketahui oleh semua anggota masyarakat pemakai bahasa tersebut, seolah-olah kode tersebut telah disepakati bersama di masa lalu di antara pemakai bahasa.

Berkebalikan dengan itu, parole merupakan bagian dari bahasa yang sepenuhnya individual. Parole dapat dipandang, pertama, sebagai kombinasi yang memungkinkan penutur mampu menggunakan kode bahasa untuk mengungkapkan pikiran pribadinya. Di samping itu, kedua, parole pun dapat dipandang sebagai mekanisme psiko-fisik yang memungkinkan penutur menampilkan kombinasi tersebut. Aspek kombinatif ini mengimplikasikan bahwa parole tersusun dari tandatanda yang identik dan senantiasa berulang. Karena adanya keberulangan inilah maka setiap tanda bisa menjadi elemen dari langue. Juga karena merupakan aktivitas kombinatif ini pulalah, maka parole terkait dengan tindakan individual dan bukan semata-mata sebentuk kreasi. Secara singkat dapat dikatakan bahwa parole merupakan penggunaan aktual bahasa sebagai tindakan individu-individu (Budiman, 2004: 38).

\section{Istilah Bahasa Agama}

Sejak Tuhan "berbicara" maka Islam lahir sebagai agama, sekaligus sebagai referensi dalam kehidupan (way of life). Seluruh kebudayaan Islam memulai langkahnya dengan fakta sejarah bahwa 
manusia di sapa Tuhan dengan bahasa yang Dia ucapkan sendiri. Dari sisi motif pewahyuan, pada mulanya manusia (Muhammad) adalah obyek dari kitab suci. Kitab suci diwahyukan Tuhan untuk menyapa manusia dan mengajaknya ke jalan keselamatan. Tetapi dalam perjalanannya, ketika wahyu telah menjelma menjadi teks, maka kitab suci berubah menjadi obyek, sementara manusia berperan sebagai subyek.

Sebelum menjelaskan pengertian bahasa agama, kiranya perlu diketahui dua macam pendekatan dalam memahami ungkapanungkapan keagamaan. Sebagaimana dijelaskan Komaruddin Hidayat, (Hidayat, 1996:73) pertama, theo-oriented, menurut teori ini yang disebut dengan bahasa agama adalah kalam Ilahi yang kemudian terabadikan ke dalam kitab suci. Menurut teori ini term Tuhan dan kalam-Nya lebih ditekankan, sehingga pengertian bahasa agama yang paling mendasar adalah bahasa kitab suci. Kedua, antropo-oriented, yang dimaksud dengan bahasa agama adalah ungkapan serta perilaku keagamaan dari seseorang atau sebuah kelompok sosial. Menurut pengertian yang kedua bahasa agama merupakan wacana keagamaan yang dilakukan oleh umat beragama maupun sarjana ahli agama meskipun tidak selalu menunjuk serta menggunakan ungkapan-ungkapan kitab suci.

Masing-masing teori di atas masih terdapat celah atau batasan yang kurang jelas. Teori yang pertama misalnya, pada akhirnya akan juga mengarah pada wacana keagamaan sehingga mencakup pengertian yang kedua, karena semua kitab suci pada urutannya akan melahirkan penafsiran baik dalam bentuk lisan maupun tulisan. Sedangkan pada teori yang kedua ada kemungkinan untuk melepaskan kitab suci, bahkan mengarah pada narasi filsafat dan ilmiah. Karena itu, kiranya perlu membuat karakterisasi tentang bahasa agama itu sendiri.

Pertama, obyek bahasa agama adalah metafisis, berpusat pada Tuhan dan kehidupan baru di balik kematian dunia. Kedua, sebagai implikasi dari yang pertama, format dan materi pokok narasi keagamaan adalah kitab suci. Dan ketiga, bahasa agama mencakup ungkapan dan ekspresi keagamaan secara pribadi maupun kelompok, 
meskipun ungkapannya menggunakan bahasa ibu. Bahasa metafisik ialah bahasa ataupun ungkapan serta pernyataan yang digunakan untuk menjelaskan obyek yang bersifat metafisikal, terutama tentang Tuhan. Karena berbagai pernyataan tentang Tuhan tidak bisa diverifikasi atau difalsivikasi secara obyektif dan empiris, maka dalam memahami kitab suci seseorang cenderung menggunakan standar ganda. Yaitu, seseorang berpikir dalam kapasitas dan berdasarkan pengalaman kemanusiaan namun diarahkan untuk suatu obyek yang diimani yang berada di luar jangkauan nalar dan inderanya. Dengan ungkapan lain, dia berpikir dalam kerangka iman dan dia beriman sambil mencoba mencari dukungan dari pikirannya.

Dalam berteologi meskipun nalar telah berusaha memahami dan menafsirkan firman Tuhan secara logis, namun pada ujungnya orang yang beragama akan pasrah pada keputusan imannya ketika dihadapkan pada firman Tuhan yang sulit dicerna akal. Karena itu, dalam memahami bahasa agama, terutama al-Qur'an dan hadis dalam berbagai hal diperlukan analogi-analogi kritis mengingat keduannya terbungkus dalam bahasa kultural Arab sedangkan kita hidup dalam kultur yang berbeda. Tanpa disadari ketika membaca dan memahami al-Qur'an sesungguhnya kita menulis ulang teks itu dalam bahasa mental yang mendominasi kesadaran batin kita, yaitu bahasa ibu (Rahardjo, 2004: 10).

Karena itu, pemahaman dan penafsiran terhadap semua teks, termasuk teks-teks al-Qur'an harus melibatkan ketiga unsur di atas. Selain itu, analisis konteks juga sangat berperan dalam memahami peristiwa pewahyuan, sebab ayat-ayat al-Qur'an tidak akan dapat dimengerti kecuali dengan melihat konteks saat wahyu diturunkan. Seseorang tidak mungkin mengerti dan dapat memahami ayat-ayat alQur'an secara utuh apabila ia mengambil teks semata, dan melupakan realitas yang melatarbelakanginya. Mengutip Mustansyir, Wittgenstein menegaskan, arti suatu kata bergantung pada penggunaannya dalam kalimat, sedangkan arti suatu kalimat bergantung pada penggunaannya dalam bahasa (Mustansyir, 2001:155). Hal ini menunjukkan bahwa kita bisa terjebak ke dalam kerancuan bahasa manakala kita menjelaskan 
pengertian suatu kata dengan memisahkannya dari situasi yang melingkupinya. Dalam tradisi Islam pemahaman selalu bersifat terbuka dan tidak pernah selesai, karena pemahaman selalu berkembang seiring dengan kemajuan umat Islam. Namun pada realitanya, komentar M. Amin Abdullah, lantaran budaya kritik epistimologis, khususnya dalam wilayah pemikiran keagamaan tidak tumbuh secara wajar dalam budaya muslim, maka pada ujungnya terjadi apa yang diistilahkan Arkoun sebagai proses taqdis al-afkar al-diniyyah (pensakralan buah pikiran keagamaan) (Abdullah, 1996:7).

Umat Islam meyakini bahwa kalam Tuhan yang paling tinggi tingkat otentisitasnya adalah al-Qur'an yang telah diwahyukan, walaupun demikian untuk memahaminya masih diperlukan teks-teks lain. Kalangan sahabat Rasul sendiri banyak menemui kesulitan sehingga kemudian dikenallah hadis yang pada dasarnya merupakan penjelasan Muhammad terhadap al-Qur'an. Di sini konsep intertekstualitas yang dikenalkan para kritikus literatur kontemporer sesungguhnya telah muncul sejak lahirnya semua kitab suci walaupun dalam hal ini terdapat perbedaan yang mendasar.

Lingkaran internal intelekstualitas al-Qur'an telah dibuka dan dimasuki oleh teks lain di luarnya, yaitu oleh Muhammad SAW dan para penafsir lain. Intertekstualitas bahasa agama lebih berkembang lagi pada masa pasca sahabat, terutama dimulai sejak abad ke-9 ketika umat Islam bertemu dengan budaya non-Arab. Literartur keagamaan klasik yang banyak dijadikan rujukan studi keislaman sekarang tidak luput dari dialog intertekstualitas antara al-Qur'an, hadis, dan teks-teks filasfat Yunani. Perkembangan ini semakin pesat ketika umat Islam semakin memperoleh pendidikan tinggi, sementara teknologi percetakan dan penerbitan menjadi trend yang menggeser budaya lisan. Dengan meluasnya lingkaran jaringan interteks bahasa keagamaan yang muncul kemudian bisa memperjelas pesan al-Qur'an.

Munculnya berbagai macam metode tafsir, seperti metode tafsir ijmali (global), tahlili (analitis), muqarin (perbandingan), dan maudlu ${ }^{i}$ (tematik) merupakan satu ikhtiyar dalam memahami ayat-ayat al- 
Qur'an. Nabi dan para sahabat menafsirkan al-Qur'an secara ijmali tidak memberikan rincian yang memadai. Karenanya di dalam tafsiran mereka pada umumnya sukar menemukan uraian yang detail. Karena itu, tidak salah bila dikatakan bahwa metode ijmali merupakan metode tafsir al-Qur'an yang mula-mula muncul. Embrio munculnya tafsir dengan metode ijmali ini kemudian diikuti oleh metode tahlili dengan mengambil bentuk al-ma`tsur, dan secara evolusi berkembang dengan mengambil bentuk al-ra yi (Baidan, 1998:3)

Tafsir dalam bentuk ini kemudian berkembang terus dengan pesat sehingga mengkhususkan kajiannya dalam bidang-bidang tertentu seperti fiqh, tasawuf, bahasa, dan sebagainya. Dapat dikatakan, corak-corak serupa inilah di abad modern yang mengilhami lahirnya tafsir maudlu $i$, atau disebut juga dengan metode maudlu $i$ yang kemudian mengilhami lahirnya metode muqarin. Lahirnya metodemetode tafsir tampak kepada kita lebih banyak disebabkan oleh tuntutan perkembangan masyarakat yang selalu dinamis. Permasalahan kehidupan di abad modern berbeda jauh dari apa yang dialami oleh generasi terdahulu. Perbedaan tersebut terasa sekali di tengah masyarakat, seperti mobilitas yang tinggi, perubahan situasi yang sangat cepat, dan lain-lain. Hadirnya pemahaman baru terhadap alQur'an dengan berbagai metode tafsir yang ditawarkan merupakan bentuk intertekstualitas bahasa agama yang tidak bisa dihindari.

\section{Semiotika: Sebuah Model Pendekatan}

Dalam dunia semiotika bahasa dianggap sebagai "tanda" (sign) yang memiliki komponen signifiant (penanda) dan signifie (petanda). Artinya, penanda dan petanda membentuk tanda, dan hubungan antar keduanya bersifat arbitrer, baik secara kebetulan maupun ditetapkan. Saussure menjelaskan, arbitrer yang dimaksud tidak berarti bahwa pemilihan penanda sama sekali meninggalkan pembicara, namun lebih dari itu adalah "tak bermotif", yakni arbitrer dalam pengertian penanda tidak mempunyai hubungan alamiah dengan petanda (Berger, 2005:12). Dengan kata lain, penanda adalah bunyi atau coretan yang bermakna. 
Jadi penanda adalah aspek material dari bahasa, apa yang dikatakan atau didengar, dan apa yang ditulis atau dibaca. Sedangkan petanda adalah gambaran mental, pikiran, atau konsep.

Sekarang persoalannya, "Bagaimana jika semiotika berhadapan dengan teks-teks bahasa agama, khususnya al-Qur'an?" Sebelum menjawab pertanyaan ini terlebih dahulu harus dipahami mengenai persoalan teks-teks bahasa agama itu sendiri. Perbincangan masalah tersebut sebenarnya merupakan persoalan klasik yang pernah muncul dalam sejarah peradaban Islam, yaitu antara pemikir Asy`ariyah dengan Mu`tazilah. Kelompok Asy`ariyah berpendapat bahwa firman Tuhan merupakan salah satu dari sifat-sifat Dzat. Dari sini mereka menyatakan, al-Qur'an adalah firman yang azali dan qadim karena ia termasuk sifat Dzat Tuhan. Masih dalam pandangan mereka, bahwa dalam al-Qur'an terdapat dua aspek, pertama, aspek yang bersifat azali dan qadim yaitu firman Tuhan dalam Dzat-Nya sendiri yang mereka istilahkan dengan "firman kedirian yang qadim". Kedua, al-Qur'an yang kita baca merupakan salinan (mimesis) dari firman archaic yang disebut pertama.

Argumen di atas berbeda dengan kelompok yang kedua, mereka berpandangan bahwa al-Qur'an itu baru dan makhluk karena ia tidak termasuk dalam sifat-sifat Dzat yang azali. Al-Qur'an adalah firman Allah, sedangkan firman termasuk tindakan, bukan sifat. Dengan demikian, al-Qur'an masuk dalam kategori "sifat-sifat tindakan Tuhan" dan bukan kategori "sifat-sifat Dzat". Kedua kategori ini dibedakannya sebagai berikut, sifat-sifat tindakan merupakan wilayah interaksi antara Tuhan dengan dunia, sementara wilayah sifat-sifat Dzat merupakan wilayah kekhususan eksistensi Tuhan dalam Dzat-Nya sendiri (tidak terkait dengan dunia) (Abu Zaid, 1994: 86).

Mengikuti pola pikir di atas, dan dikaitkan dengan paradigma yang digagas Ferdinand de Saussure dapat diperoleh satu pemahaman bahwa konsep kalam (firman Tuhan) berbeda dengan konsep lughat. Lughat yang dimaksud setara dengan apa yang diistilahkan Saussure dengan langue, yaitu bahasa pada wilayah realitas historis yang dalam 
hal ini merupakan bagian dari kebudayaan. Dalam pengertian umum, langue adalah abstraksi dan artikulasi bahasa pada tingkat sosial budaya, sedangkan parole merupakan ekspresi bahasa pada tingkat individu (Hidayat, 1996: 23).

Dengan demikian, terdapat perbedaan yang tegas antara konsep kalam (yang ahistoris) dengan lughat (historis). Dengan mengikuti kerangka berpikir Saussure di mana obyek studi linguistiknya menitiberatkan pada bahasa sebagai proses langue maka tanda-tanda bahasa merupakan fakta sosial. Karena tanda-tanda bahasa tidak mengarah pada realitas eksternal-obyektif secara langsung, tetapi mengacu pada konsep dan gambaran mental yang berdiam dalam kesadaran masyarakat, maka ini berarti bahwa bahasa barada dalam inti kebudayaan, sekalipun terejawantah dalam berbagai manifestasi. Dari sini para ahli semiotika mengatakan bahwa kebudayaan adalah ekspresi dari berbagai sistem tanda yang inti pusatnya adalah sistem tanda bahasa. Jika semiotika dipahami sebagai ilmu tentang tanda maka alQur'an khususnya konsep langue atau lughat yang historis menjadi bidang subur bagi analisis semiotis, bukan parole atau firman yang ahistoris.

Berkaitan dengan wacana yang berkembang dalam tradisi hermeneutika, bahwa makna teks itu akan selalu berubah-rubah maka kita dapat mencermati konsep makna yang dikembangkan Nasr Hamid (Abu Zaid, 1994:209). Ia menyatakan, kajian terhadap teks keagamaan makna dapat dibedakan menjadi 2 (dua) macam, yaitu: 1) makna yang khusus (tarikhi), dan 2) makna yang umun (daim mustamirr). Yang khusus merupakan sisi semantik yang secara langsung mengacu pada realitas kultural-historis untuk memproduksi teks, sementara yang umum merupakan sisi dinamis, dapat berubah seiring dengan setiap pembacaan. Dengan kata lain, perbedaan tersebut merupakan perbedaan antara makna parsial yang temporal dengan makna umum yang universal. Yang partikular dapat berubah melalui interpretasi metaforis menjadi universal. 
Dari penjelasan di atas dapat dimengerti bahwa makna teks-teks agama bersifat historis, sehingga makna yang ditimbulkan bergantung pada sistem bahasa dan budaya di mana ia merupakan bagian darinya. Historisitas teks bukan hanya berupa ruang dan waktu (asbab al-nuzul), tetapi penerima bahasa beserta realitas sosio-kultural yang melingkupi juga merupakan teks yang dapat menentukan fleksibilitas makna. Karena itu (seperti yang diungkap Barthes) dalam teks-teks bahasa agama mengenal istilah makna tingkat pertama (denotatif) dan juga makna tingkat kedua (konotatif). Makna denotatif adalah makna secara leksikal, sementara makna konotatif adalah makna yang melibatkan unsur kesejarahan teks (asbab al-nuzul) dan latar sosio-kultural pembaca teks itu sendiri. Sehingga pemahaman terhadap makna teks tidak pernah final, tetapi terus berkembang seiring dengan kemajuan umat manusia.

Misalnya kata ashnam (berhala), kalau pada masa Nabi Ibrahim hingga masa Nabi Muhammad saat beliau menyampaikan dakwahnya di tengah-tengah kehidupan umat makna ashnam sangat jelas merujuk pada berhala, patung, arca, atau sejenisnya. Namun dalam konteks sekarang makna ashnam barangkali tidak sebatas itu, mungkin berupa jabatan, kedudukan, kekayaan, dan sebagainya yang kesemuanya dapat melalaikan kepada Allah, bahkan mensekutukan-Nya. Artinya, makna kata ashnam tersebut tergantung dalam situasi dan konteks apa kita mengungkapkannya. Begitu juga dengan kata-kata lainnya, seperti nur, habbah, jannah, nar, dan syaithan.

Letak urgensi semiotika sebagai pendekatan terhadap teks-teks bahasa agama adalah karena adanya proses signifikasi. Yaitu sebuah usaha untuk memberikan makna terhadap dunia sebagai tanda. Selain itu, dengan mengikuti paradigma yang dibangun Barthes, bahwa dalam proses signifikasi tidak hanya mengenal makna denotatif semata, tetapi juga memperlihatkan makna konotatif yang itu terkait dengan mitos. Istilah signifikasi berbeda dengan istilah makna, dalam bahasa Nasr Hamid signifikasi diistilahkan dengan manghza yang itu lebih luas dari pada makna. Makna merupakan apa yang dipahami secara langsung dari teks yang diartikulasikan, muncul dalam struktur bahasa dan 
dalam konteks kebudayaannya. Ini merupakan pemahaman yang diperoleh oleh seseorang yang sezaman ketika teks tersebut diproduksi. Perbedaan antara "makna" dan "signifikasi" (manghza) terfokus dalam dua dimensi yang tidak terpisah. Dimensi pertama, makna memiliki ciri historis, ia dapat diperoleh melalui pengetahuan konteks linguistik (internal) dan konteks kultural-sosiologis (eksternal). Sementara signifikasi, meskipun tidak dapat dipisahkan dari makna memiliki corak kontemporer dalam pengertian ia merupakan hasil dari pembacaan masa di luar terbentuknya teks. Dimensi kedua, sebagai konsekuensi dari dimensi pertama bahwa makna memiliki aksentuasi yang relatif stabil, sementara signifikasi memiliki corak yang bergerak seiring dengan perubahan horison pembacaan, meskipun hubungannya dengan makna mengarahkan geraknya (Abu Zaid, 1994:221).

Signifikasi pada prinsipnya merupakan semiotika tingkat langue. Dalam kerangka ini, Saussure menjelaskan, tanda sebagai kesatuan yang tidak dapat dipisahkan dari 2 (dua) bidang, yaitu: 1) penanda (signifiant/yang mengartikan) dan 2) petanda (signifie/yang diartikan). Penanda menjelaskan bentuk atau ekspresi, dan petanda menjelaskan konsep atau makna. Dalam keterkaitan dengan tanda, Saussure menekankan konvensi sosial yang mengatur kombinasi tanda dan maknanya. Relasi antara penanda dan petanda berdasarkan konvensi sosial inilah yang disebut signifikasi. Dengan kata lain, signifikasi adalah upaya dalam memberikan makna terhadap dunia (Fiske, 90:44).

Relasi ini digambarkan Roland Barthes untuk menghasilkan makna yang bertingkat, yaitu makna konotasi dan denotasi. Konotasi adalah istilah yang digunakan untuk menunjukkan signifikasi tahap kedua. Konotasi mempunyai makna yang subyektif, atau paling tidak intersubyektif. Denotasi adalah apa yang digambarkan tanda terhadap sebuah obyek. Sedangkan konotasi adalah bagaimana menggambarkannya. Pada signifikasi tahap kedua yang berhubungan dengan isi, tanda bekerja melalui mitos.

Teori mitos yang dikembangkan Barthes adalah untuk melakukan kritik atas ideologi budaya massa. Mitologi menjadi bagian 
dari semiotika sejauh mitologi merupakan ilmu formal, dan menjadi bagian ideologi sejauh mitologi menyangkut ilmu sejarah, yaitu mempelajari ide-ide dalam bentuk. Dengan definisi ini, mitologi merupakan bidang yang bisa dipelajari baik oleh semiotik maupun ideologi. Mitos biasanya dipakai untuk menunjuk cerita yang tidak benar, cerita buatan yang tidak mempunyai kebenaran historis. Meskipun demikian, cerita semacam itu tetap dibutuhkan agar manusia dapat memahami lingkungan dirinya. Mitos menjadi salah satu tema kajian menarik di lingkungan antropologi. Ciri mitos dan fungsinya inilah yang coba diteorisasikan oleh Barthes dengan menggunakan pendekatan semiotik. Dia menemukan bahwa orang modern pun dikerumuni oleh banyak mitos, orang modern juga produsen dan konsumen mitos. Mitos-mitos ini tidak hanya kita dengar dari orangorang tua dan buku-buku tentang cerita lama, melainkan kita temukan setiap hari di televisi, radio, pidato, dan sebagainya (Sunardi, 1996:103)

Sebagai sistem semiotik tingkat dua, mitos mengambil sistem semiotik tingkat pertama sebagai landasannya. Jadi, mitos adalah sejenis sistem ganda dalam sistem semiotik yang terdiri dari sistem linguistik dan sistem semiotik. Untuk menghasilkan sistem mitis, sistem semiotik tingkat dua mengambil seluruh sistem tanda tingakat pertama sebagai signifier atau form. Kalau kita memperhatikan kerangka berpikir Barthes kita pasti akan menyimpulkan bahwa mitos adalah sejenis konotasi. Dari skema yang diberikan Barthes kita melihat bahwa sistem tanda tingkat pertama dijadikan signifier baru bagi sistem tanda tingkat dua. Dengan kata lain, tanda denotatif sebagai tanda tingkat pertama yang terdiri atas penanda dan petanda, pada saat bersamaan tanda denotatif juga menjadi penanda bagi tanda konotatif. Seperti tanda "singa", makna denotatifnya adalah hewan buas, sementara konotasinya mungkin berarti harga diri, kegarangan, dan keberanian. Dalam mythologies Barthes dengan tegas dikatakan bahwa mitos adalah sejenis metabahasa.

Semiotika struktural yang dikembangkan Saussure yang mengandalkan pada kestabilan dan kemantapan tanda, kode dan makna agak bertentangan dengan semiotika yang dikembangkan Derrida 
(salah seorang pemikir post-strukturalisme). Bila pada semiotika konvensional yang ditekankan adalah proses signifikasi, yaitu memfungsikan tanda sebagai refleksi dari kode-kode sosial yang telah mapan, maka dalam semiotika post-strukturalisme yang ditekankan adalah proses significance, yaitu sebuah proses penciptaan kreatif tanda dan kode-kode yang tanpa batas dan tak terbatas (Piliang, 2001:310). Dalam proses significance terdapat kesamaan dengan teori dekonstruksi yang digagas Jacques Derrida, ia menyatakan bahwa dekonstruksi adalah sebagai alternatif untuk menolak segala keterbatasan penafsiran ataupun bentuk kesimpulan yang baku.

Konsep dekonstruksi pada dasarnya dimaksudkan untuk menghilangkan struktur pemahaman tanda-tanda (signifier) melalui penyusunan konsep (signified). Strategi dekonstruksi dijalankan dengan asumsi bahwa filsafat Barat bisa mempertahankan ide tentang pusat sebagai kehadiran murni hanya dengan cara menekan efek-efek mataforis dan figuratif yang menjadi karakter bahasa. Bila dikaitkan dengan linguistik struktural Saussurean, apa yang dikembangkan Derrida lebih jauh dari proses differance adalah penolakannya pada petanda absolut. Selalu saja ada celah di antara penanda dan petanda, antara teks dan maknanya. Disebabkan oleh celah inilah pencarian makna absolut mustahil (Piliang, 2001:127). Di kalangan filsuf yang mempunyai minat pada bahasa, seperti Jacques Derrida, petanda terakhir tidak selalu diakui. Bagi Derrida, bahasa adalah metafora yang tidak mempunyai rujukan final. Makna muncul karena pertukaran metafora, dan makna akan berubah ketika para pelakunya juga berubah. Dengan kata lain, makna selalu bersifat dinamis dan relasional, karena itu rujukannya bersifat tak terbatas (Sunardi, 1996:76).

Juga seperti yang disampaikan Khaled M. Abou El-Fadl (ElFadl, 2004:213), resiko penutupan dari sebuah teks adalah bahwa teks akan dipandang tidak relevan lagi. Penetapan makna terakhir yang dilekatkan pada teks akan menyegel makna teks untuk selamanya. Teks menjadi tidak relevan, dalam arti bahwa para pembaca tidak punya alasan untuk kembali merujuk kepada teks dan menggelutinya. Menutup teks adalah bentuk kesombongan intelektual. Pembaca 
mengkalim, bahwa ia memiliki suatu pengetahuan yang identik dengan pengetahuan Tuhan. Akibatnya, teks asli kehilangan otonominya, dan ia menjadi teks yang bergantung pada pihak lain. Lebih lanjut Khaled menyatakan, Tuhan, al-Qur'an dan Nabi adalah yang berhak memegang otoritas dalam Islam. Maksudnya, jika ada seseorang yang mengklaim bahwa pendapatnya yang paling benar maka secara tidak langsung ia sudah "menyamakan" dirinya dengan pemegang otoritas yang sebenarnya.

Misalnya, dalam al-Qur'an kita temukan dalam banyak ayat kata fuqara 'dan masakin. Secara normative, kita melihat fuqara' dan masakin sebagai kelompok yang perlu dikasihani dan diberikan zakat atau sedekah. Pada hal kata fuqara dan masakin merupakan simbol atau tanda (penanda/signifiant) yang perlu diinterpretasi dan dicari rujukannya (petanda/signifie) dalam konteks yang lebih real, faktual, serta sesuai dengan kondisi sosial, ekonomi dan kultural. Begitu juga dengan istilah yatim, secara syar $i$ adalah orang yang ditinggal ayahnya. Dalam rumah tangga seorang ayah berfungsi untuk memberikan perlindungan, keamanan, kesejahteraan, dan sebagainya. Tatkala orang yang mampu memberikan segalanya ini telah tiada maka sang anak disebut yatim karena ia sangat membutuhkan pertolongan terkait dengan masa depannya. Fenomena seperti ini sering kita temukan dalam bentuk yang berbeda, namun memiliki substansi yang sama. Seseorang dengan kekuasaan dan jabatan strategis yang disandangnya terkadang menutup muka ketika melihat orang-orang yang terisolir akibat kebijakan-kebijakan politis. Sekelompok orang tergusur dari posisinya akibat perbedaan ideologi dan pandangan hidup dengan atasannya. Juga dengan pejabat pemerintah terkadang apatis ketika melihat orang-orang yang dirampas hak-haknya. Secara sosiologis, kondisi mereka yang memerlukan bantuan orang lain untuk mempertahankan eksistensi kehidupannya dapat dikategorikan sebagai anak "yatim". Pengertian semacam ini yang dimaksud Barthes dengan makna tataran kedua, konotatif, atau yang populer disebut mitos.

Seorang penafsir akan mencoba membayangkan apa yang dikehendaki oleh teks pada masa lalu jika ia kembali digubah pada 
masa kini. Makna dapat dan harus melampaui konteksnya. Kita memahami teks dalam konteks masa lalu bukan untuk memahami makna sebenarnya dari teks itu, tapi untuk memahami dinamika antara teks dan penerima awalnya. Jika Tuhan benar-benar berbicara untuk semua masa dan generasi, maka teks al-Qur'an tidak dapat dipahami sebatas konteks historisnya saja. Kita memahami, bahwa teks al-Qur'an adalah hasil proses dialektis dan jawaban Muhammad atas konteks Arab saat itu. Sehingga al-Qur'an itu didesain, dikonstruk dan diinterpretasi sesuai dengan konteksnya. Pemahaman baru terhadap alQur'an bukan berarti mereduksi, tetapi membuktikan sejauh mana alQur'an mampu berdialog dengan realitas. Sebab itu, teks harus dimaknai kembali secara lebih komprehensif, inklusif dan substantif untuk menghindari pemahaman yang parsial, eksklusif dan formalistik. Dengan begitu, Islam yang diyakini sebagai agama shalihun li kulli zamanin wa makanin dan membawa misi rahmatan lil 'alamin bukan saja menjadi retorika, melainkan sebuah kenyataan.

\section{Penutup}

Dalam dunia semiotika bahasa dianggap sebagai tanda (simbol atau lambang), tanda adalah kesatuan dari suatu bentuk penanda dengan sebuah ide, atau petanda. Penanda adalah bunyi atau aspek material dari bahasa, sedangkan petanda adalah gambaran mental, konsep, atau makna. Setiap tanda linguistik terdiri dari unsur bunyi dan unsur makna. Kedua unsur ini adalah unsur dalam-bahasa (intralingual) yang biasa merujuk atau mengacu kepada referen yang merupakan unsur luar-bahasa (ekstralingual).

Jika semiotika dipahami sebagai ilmu tentang tanda, maka alQur'an khususnya konsep langue atau lughat yang historis menjadi bidang subur bagi analisis semiotis. Karena teks-teks agama merupakan teks-teks manusiawi lantaran ia terkait dengan bahasa dan peradaban dalam rentang sejarah tertentu, yaitu masa formatisasi dan produksinya, sehingga maknanya tidak terlepas dari sistem bahasa dan budaya di mana teks dianggap sebagai bagian darinya. Maka keberadaan bahasa 
dan lingkungan kulturalnya menjadi rujukan untuk menemukan maknanya.

Urgensi semiotika sebagai pendekatan terhadap teks-teks bahasa agama adalah karena adanya signifikasi. Yaitu sebuah proses untuk memberikan makna terhadap dunia sebagai tanda. Selain itu, dengan mengikuti paradigma yang dibangun Barthes dalam proses signifikasi tidak hanya mengenal makna pada tataran pertama atau denotatif, tetapi juga mengenal makna pada tataran kedua, yaitu makna konotatif. Pengertian signifikasi ini semakna dengan teori dekonstruksi yang menolak segala keterbatasan penafsiran, bentuk kesimpulan yang baku, atau petanda absolut. Teori ini beranggapan bahwa antara penanda dan petanda, antara teks dan maknanya selalu ada celah. Artinya, makna selalu bersifat dinamis dan relasional karena konteks pelakunya juga berubah. Sebab itu, sebuah teks harus dimaknai kembali secara lebih komprehensif dan inklusif untuk menghindari pemahaman yang parsial dan formalistik. $\square$

\section{DAFTAR PUSTAKA}

Abdullah, M. Amin. 1996. Arkoun dan Kritik Nalar Islam dalam Tradisi Kemodernan dan Metamodernisme Memperbincangkan Pemikiran Arkoun, Johan Hendrik Meuleman (Ed.). Yogyakarta: LkiS.

Abu Zaid, Nasr Hamid. 1994. Naqd al-Khithab al-Diniy. Kairo: Jumhuriyah Misr al-Arabiyah.

Al-Nabhan, M. Faruq. 1981. al-Madkhal Li al-Tasyri al-Islami. Beirut: Dar al-Qalam.

Baidan, Nashruddin. 1998. Metodologi Penafsiran al-Qur'an (Yogyakarta: Pustaka Pelajar. 
Berger, Arthur Asa. 2005. Tanda-Tanda dalam Kebudayaan Kontemporer: Suatu Pengantar Semiotika. Yogyakarta: Tiara Wacana.

Bertens, K. 2001). Filsafat Barat Kontemporer Prancis. Jakarta: Gramedia.

Budiman, Kris. 2004. Semiotika Visual. Yogyakarta:Buku Baik.

Budiman, Manneke. 1995. Tuhan dalam Mimesis: Representasi Tuhan dalam Paradiso dan Bhagavadgita., dalam Jurnal Ulumul Qur`an, Nomor 2, Volume VI.

Chaer, Abdul. 1994. Linguistik Umum. Jakarta: Rineka Cipta.

Eco, Umberto. 1976. A Theory of Semiotics. Bloomington: Indiana University Press.

El-Fadl, Khaled M. Abou. 2004. Atas Nama Tuhan: Dari Fikih Otoriter ke Fikih Otoritatif, terj. R. Cecep Lukman Yasin. Jakarta: Serambi Ilmu Semesta.

Endraswara, Suwardi. 2003. Metodologi Penelitian Sastra: Epistemologi, Model, Teori dan Aplikasi. Yogyakarta: Pustaka Widyatama.

Fiske, John. 1990. Introduction to Communication Studies. London: Methuen.

Hidayat, Komaruddin. 1996. Memahami Bahasa Agama: Sebuah Kajian Hermeneutik. Jakarta: Paramadina.

Junus, Umar. 1998. Karya Sebagai Sumber Makna: Pengantar Strukturalisme. Kuala Lumpur: Dewan Bahasa dan Pusat Kementreian Pendidikan Malaysia.

Kaelan. 1998. Filsafat Bahasa: Masalah dan Perkembangannya. Yogyakarta: Paradigma.

Mustansyir, Rizal. 2001. Filsafat Analitik: Sejarah, Perkembangan, dan Peranan Para Tokohnya. Yogyakarta: Pustaka Pelajar.

Piliang, Yasraf Amir. 2001. Sebuah Dunia Yang Menakutkan: Mesin-Mesin Kekerasan dalam Jagat Raya Chaos. Bandung: Mizan.

--. 2001. "Struktur, Tanda dan Permainan dalam Wacana Ilmu Humaniora," dalam Bahasa Dekonstruksi ala Foucault dan Derrida, Dadang Rusbiantoro (Ed.). Yogyakarta: Tiara Wacana. 
Rahardjo, Mudjia. 2004. Wacana Kebahasaan dari Filsafat Hingga SosialPolitik. Malang: Cendekia Paramulya.

Sobur, Alex. 2001. Analisis Teks Media: Suatu Pengantar Untuk Analisis Wacana, Analisis Semiotik, dan Analisis Framin. Bandung: Rosda Karya.

Sunardi, St. 1996. "Membaca Qur'an Bersama Muhammed Arkoun", dalam Tradisi, Kemodernan dan Metamodernisme: Memperbincangkan Pemikiran Muhammed Arkoun, Johan Hendrik Meuleman (Ed.). Yogyakarta: LkiS.

Zoest, Aart Van. 1996. Interpretasi dan Semiotika dalam Serba-Serbi Semiotika. Jakarta: Gramedia Pustaka Utama. 